\title{
THE QUALITY OF STUDIES: MANAGEMENT ASPECT
}

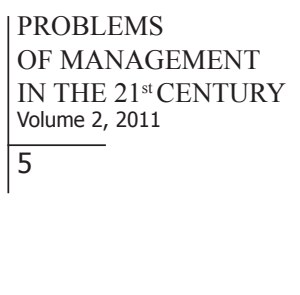

Vincentas Lamanauskas University of Šiauliai, Lithuania E-mail: v.lamanauskas@ef.su.It

In recent years attention to quality of studies is not decreasing. Lots of different level and type articles have been written, books and other literature have been published. On the other hand, over the last few years different national, regional and international science conferences and symposiums took place. Some of them can be mentioned. In November, 2000, "International Conference on Quality Assurance in Higher Education: Standards, Mechanisms and Mutual Recognition" took place in Thailand. One of the main accents in this conference was the question on how to establish new mechanisms of quality assurance and quality improvement (Harman, 2000). In October, 2010, an international conference took place on Quality Assurance in Higher Education in Africa: Setting a Sustainable Agenda for a New Decade (http://www. unesco-bamako.org/conferences/). In February, 2001, 10th International Research Conference on Quality, Innovation \& Knowledge Management (http://www.buseco.monash.edu.au/mgt/ qik-conference/) took place in Malaysia. There's no purpose in mentioning all conferences that were held. All of them were significant in their own way. After all, different events on university study quality questions are regularly organised by international organisations such as, for example, European University association (http://www.eua.be/Home.aspx). One of the mottos of EUA organisation is - strong universities for Europe. So, it is obvious, that the concern in the university study quality is really huge. However, the essence of the matter lies somewhere deeper. The main goals, formulated in Bologna declaration, had to be implemented by 2010. However, now it becomes clear, that some of the vitally important things were not realised and there are more and more doubts if they will, on the whole, be carried through. The Bologna process itself is not sought to be analysed. What interests us firstly, is the quality of studies' management question. Various researches reveal that the university study quality in some countries has significantly decreased even measuring according to the most minimal criteria. First of all, this is because most universities are oriented into providing service. It is known, that service University is not capable to ensure the proper quality of the studies and of provided education at the same time. Mass universities meant for mass usage. University education is more and more "Mc.Donaldized" (Lamanauskas, 2011a).

Going back to Bologna process, it is worth to notice that the question of quality in the mentioned declaration is not the basic. In the declaration it is said, that Bologna process members' cooperation is important seeking to evaluate the quality on the basis of inter-comparative criteria and methods. During the period after the announcement of Bologna declaration, negative, opposing ideas were in fact, getting stronger as well. It is natural in this sense, that every country is peculiar, social-cultural and political-economical context of the countries is rather distinctive. In such different contexts, complex functional links and various patterns exist. It is likely, that this is one of the reasons why Bologna process was not going and is not going so as it was believed. Both students and teachers regularly, in different forms express dissatisfaction with the current situation. For example, a new law on science and studies came into force in Lithuania as far back as 2009. A new study fee system - student's basket - was legitimated. In other words, students, entering state higher schools, having received state financing, so-called 
PROBLEMS

OF MANAGEMENT

IN THE $21^{\text {st }}$ CENTURY

Volume 2, 2011

6

"study basket", don't have to pay any other fees related with the studies. In Lithuania, in 2009, about 21 thousand of freshmen were admitted to study in the places financed by the state: 11 thousand -to universities, 10 thousand - to colleges. In the later years political attitudes were changing. The number of financed places at state universities is consecutively diminishing. It is paradoxical, however, in the preamble of a new mentioned law it is written that "The mission of science and studies is to help assure the prosperity of the country society, culture and economy" http://www3.lrs.lt/pls/inter3/dokpaieska.showdoc_1?p_id=343430\&p_query=\&p_tr2=).

However, it is impossible to implement such mission without strengthening universities in all possible ways, and not devoting proper attention to them. It is urgent not only to Lithuania but to smaller European states as well. For the universities of such countries it is difficult indeed to survive in global and aggressive market, where quite often money determines everything. It can be stated, that quite often some universities complete the number of students not according to their knowledge and abilities, but according to their financial power. Thus, the student who brings money to university is expected. And it doesn't matter in what form -whether it is study basket or any other. The most important is to survive in market. Thus, in this respect study quality becomes a subject of minor importance. It is clearly understandable, that study quality directly depends on science quality. The studies have to be based on the newest science achievements. Unfortunately, in many cases there is not so. Universities become very ordinary schools where relatively not bad teachers work, conveying the truths of the textbooks. Free attitude to studies, free attendance of the lectures, orientation only to student needs (sometimes pseudo needs) almost don't leave place for fundamentality, which is the basis of good education. The duration of studies is being diminished, claiming that education can be acquired during the shorter time. And where are these limits of cleverness and rationality? This is management question. One of the aspects is study quality mythologization. In some European countries, especially in post-soviet ones, a stereotypical thinking is still vital, isn't it? This reveals itself in different ways. Study programmes are assessed, old study programmes are re-written, naming it improvement, different self-appraisals and reports are arranged, development is imitated and so on. On the other hand, it can be seen, that practically funds are not allotted for raising teachers and scientists' qualification, for the renewal of scientific research base (equipment, laboratories and other). Students also very often choose higher education only for diploma; they are not motivated to seek professional development. A lot of examples could be presented, however this is not the aim of this article. It is obvious, that a rather wide disparity remains between modern declarations and current practice. The lack of systemic thinking in higher education management sphere is not only real, but it becomes even dangerous (Lamanauskas, 2011b).

The other aspect is risk management in higher education. The quality of studies can't be analysed separately from all university and other processes taking part in it. The quality of conditions, processes and results is a universal very resiliently related triad. In other words, university work is specific in many respects and here classical risk management patterns quite often don't suit or don't function properly. For example, rather often employers complain that contemporary university preparation is not proper, that young people, having finished universities, hardly adapt themselves in the labour market, preparation is very theoretical, so enterprises and other organisations are made to re-teach specialists in their working place. For this, undoubtedly, extra investments are necessary. This is one of the risks for a concrete enterprise fail to achieve necessary productivity due to insufficient qualification of the workers. University education importance can be discussed in many ways however the fact is obvious, that universities are still estranged from today's labour market. Here is one example. Let's say, in recent years quite a lot of lawyers have been trained in Lithuania. Law study programmes are almost in all universities and in some colleges. However, when more serious judicial problems arise, government looks for law specialists behind the boundaries of the country. This tendency is observed not only in Lithuania, but in some other European countries as well. Without doubt, 
there are a lot of other risks. Therefore, it is important, that risk management ensuring the quality of studies remains very urgent.

Thus, good higher education is really very expensive and is hardly achievable. It is paradoxical, that it is less and less valued. The power of "attraction" between universities and employers is changed by the power of "repulsion". The latter is getting stronger and stronger. How to reduce this always growing distance between two sides? How to escape the produce of "fault" for always growing price? Good examples occur. How to coordinate very different interests of the employers? Quite often universities are blamed for preparing the youth too academic, "bookish", almost not having any practice. The middle and small business sectors need people, having bigger practical experience, after all, such employers are content with the cheaper working force. On the contrary, large business representatives require high qualification workers with big theoretical and creative power, capable to create (generate) and realise ideas.

Thus, the problem of the quality of studies remains the key problem in nowadays university work. It is understandable, that different countries have different experience in this field both in horizontal and vertical sense. The quality of studies conception despite all efforts remains diverse and has multiple meanings. Paraphrasing a familiar soviet times' statement ("from everyone - according to possibilities, for everyone - according to demands"),one can state, that higher education can't be provided according to demands, and it can't be required from graduates according to their abilities and possibilities. Massification of higher education in a direct way negatively affects the quality of studies (process), as well as higher education quality (result). This is the essential risk in university management.

\section{References}

Harman, G. (Ed) (2000). Proceedings of the International Conference on Quality Assurance in Higher Education: Standards, Mechanisms and Mutual Recognition (Bangkok, Thailand 8-10 November 2000). Bangkok. Available on the internet: http://unesdoc.unesco.org/images/0012/001278/127860e.pdf (Retrieved 22/112011).

Lamanauskas, V. (2011a). The "McDonald"s-ization“ of Education: Search for Fast Results. Problems of Education in the 21st Century (Recent Issues in Education - 2011), Vol. 34, p. 5-8.

Lamanauskas, V. (2011b). Perspective Management: Systemic Thinking and Value Synergy Necessity. Problems of Management in the 21st Century (Topical Issues in Management - 2011), Vol. 1, p. 5-6. 